\title{
Towards Informed Use of the Pernkopf Atlas
}

\author{
Leila Lax, B.A., B.Sc.A.A.M., M.Ed., Ph.D.
}

Knowledge of the dark history and inherent ethical dilemmas of Pernkopf's atlas is essential to individual decisions on use. Seventy-five years after the Holocaust, the legacy of Pernkopf's Atlas of Topographical and Applied Human Anatomy continues to unfold. Informed use of the atlas needs to be integrated in academia and in practice. This paper advocates for the adoption of The Vienna Protocol and improving informed use of the atlas by: (1) updating and inserting an information letter in as many volumes as possible, so that the history can be known before use; (2) conducting and publishing a research study within the medical art community, to examine knowledge of the history of the atlas and elevate awareness; and (3) creating a museum archive and permanent exhibition of the original anatomical illustrations, to document historical facts, disseminate visual evidence, and illuminate embedded controversies. Moving towards informed use, in these ways, provides opportunities for continued ethical discourse, personal reflection and future Holocaust education. Through informed use we memorialize and pay tribute to the Nazi victims portrayed in the atlas.

\section{OPEN ACCESS}

As a medical art student in the Department of Art as Applied to Medicine, in the Faculty of Medicine, at the University of Toronto from 1980-1983 and as a practicing professional, Pernkopf's Atlas of Topographical and Applied Human Anatomy (1980) and Grant's Atlas of Anatomy (1978) were always on my desk. They were my primary sources of reference.

Grant's Atlas is a regional anatomical atlas that was created at the University of Toronto by anatomist Dr. John C. Boileau Grant and illustrated by Dorothy Foster Chubb and other medical artists, including the first, academic director of the Bachelor of Science program in Art as Applied to Medicine, Prof. Nancy Grahame Joy.
Grant's Atlas has been revised, digitized and colorized over the last 30 years by Dr. Anne Agur in collaboration with Dr. Arthur Dalley from Vanderbilt University and teams of medical artists, led by University of Toronto professors, David Mazierski in the 1990's and Nicholas Woolridge in 2016.

The original anatomical illustrations for Grant's Atlas were created in greyscale carbon dust and wash techniques and printed in black and white half-tones (Figure 1). Color overlays were often used - yellow for nerves, red for arteries and blue for veins, to clarify structures for didactic purposes. Key structures were labelled to provide the intended educational focus, along with figure titles that also conveyed view orientation. Grant's Atlas was conceived of as a companion to anatomical dissection for pedagogic purposes, not for surgical reference; it is for this reason that Grant's Atlas and Pernkopf's atlas are distinctly different. Grant's Atlas was and continues to be a primary resource for undergraduate and graduate anatomy, medical, health professional, and allied health education.

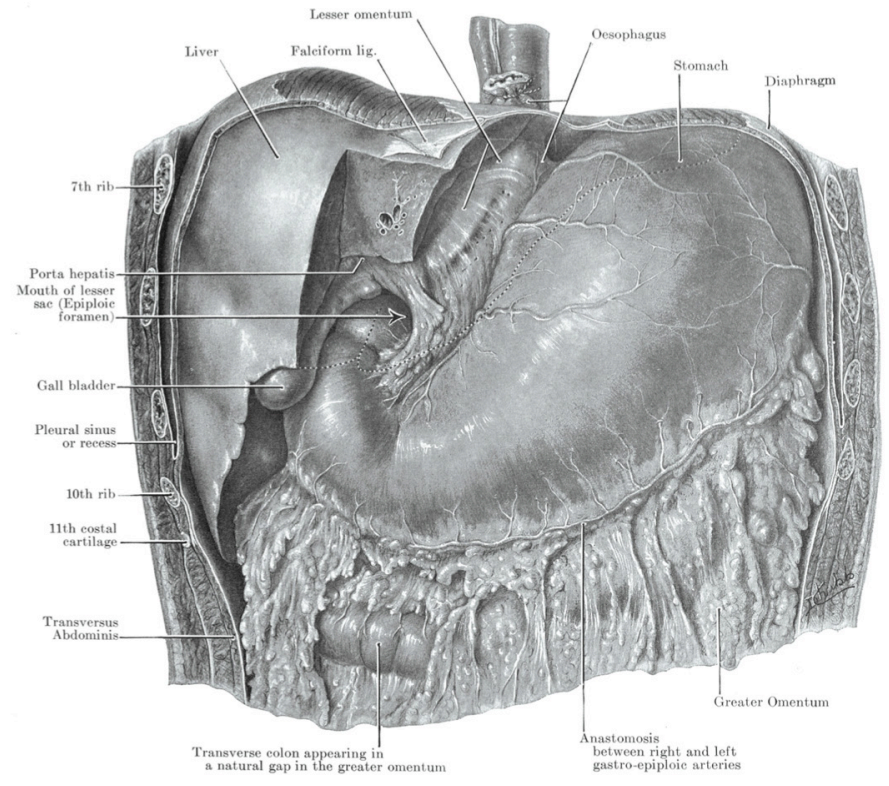

Figure 1. Grant's Atlas (1978, fig. 2-28) stomach and the omenta, front view. Permission provided by Wolters Kluwer. 
The Pernkopf atlas anatomical illustrations were rendered and labelled in significantly greater detail and painted in full color, in a style that gave the illusion of in-situ visualization. The meticulously dissected anatomical specimens, although preserved and colorless in reality, were painted by the Pernkopf artists in a lifelike manner, using vivid tissue color, specular, "wet" highlights and reflections. The extraordinary hyperrealism and extreme detail in the rendering of these anatomical visualizations was matched by highly specific labels and an array of well-organized, fine leader lines. In fact, after the first printing of the atlas the number of labels were reduced in future publications, and yet still remain the most detailed of any atlas. The Pernkopf atlas was the first anatomical atlas printed in full color. The detailed dissection, painting, labelling and printing techniques enable pinpointing of anatomical structures for immediate identification and clarification of relationships.

The organization of the pages of the atlas highlight the topographical stratification of the layered anatomical illustrations, that are typically arranged from superficial to deep visualizations. The intended orientation acknowledged by the editor in the Preface of the 1980 edition of the Pernkopf atlas was that it was created "with a view toward the needs of the surgical specialties" (Ferner, in Pernkopf). Hence, as Dr. Susan Mackinnon and colleagues indicate the Pernkopf atlas can be an important resource in surgery $(2021 ; 2019$ a; $2019 b$ ) and similarly, as Dr. Anne Agur demonstrates (2021), the tracing of structures through stratified visualizations can be useful in clinical diagnosis. The anatomical information encapsulated in these meticulously rendered and labelled visualizations remain unmatched in any other full color or greyscale print or digital atlas.

As a medical art student, I was enthralled by the anatomical details and exceptional watercolor technique used in the Pernkopf illustrations. So much so that I did exercises to master the artists' techniques and use of color. Figure 2 is an example of one such exercise that I did in 1982. It is a compilation of 3 Pernkopf anatomical illustrations from the 1980 publication, volume 2, Figure 237 by Batke dated 1940 and Figures 225 and 261 by Lepier (no date) (Figures 2.a., 2.b., 2.c.). The Pernkopf artists employed the classic style of Renaissance painters, using cool blues, greens and purples in the shadows (never any grey to shade or create form), warm yellows and whites in the contrasting highlights and reflected color in adjacent structures, to achieve a high level of realism and aesthetic balance.

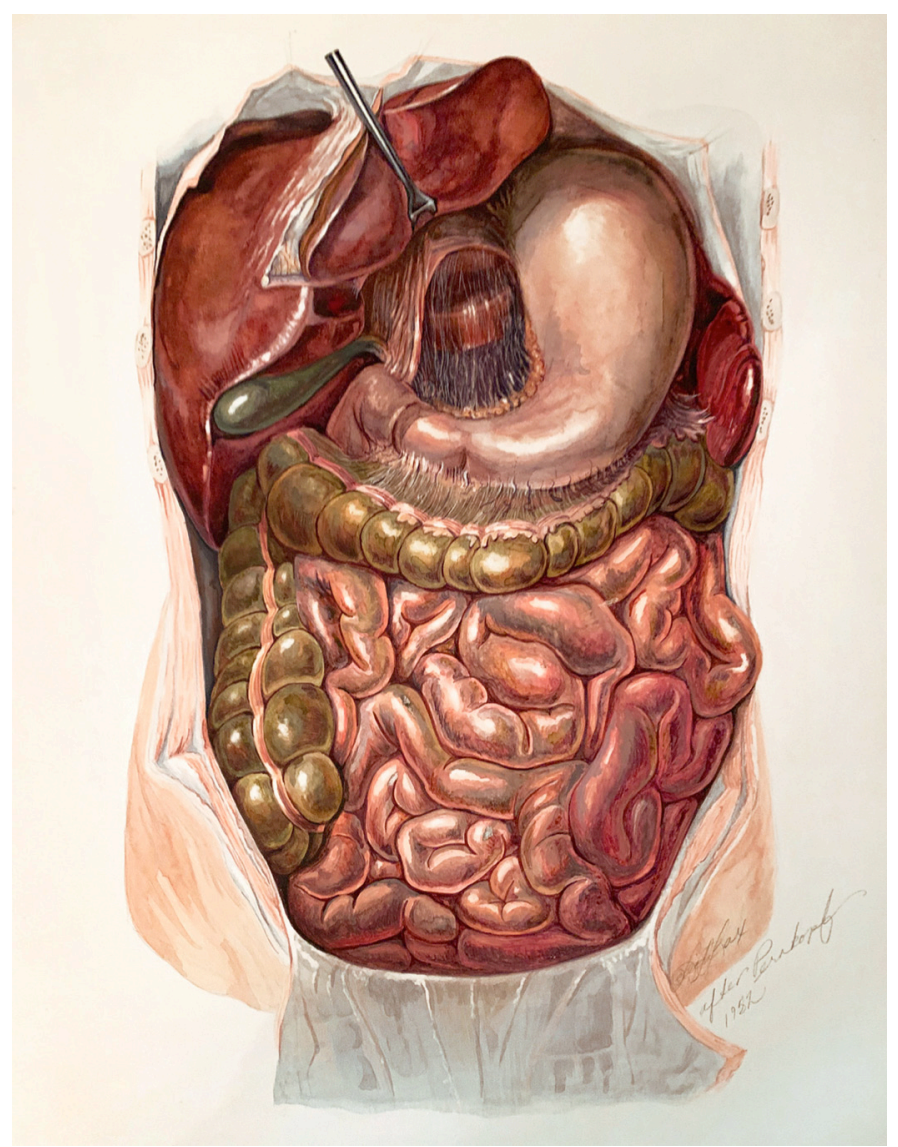

Figure 2. Student exercise after Batke \& Lepier by L. Lax (1982), based on figures 237, 261 and 225, from Pernkopf's atlas, volume 2, 1980. 


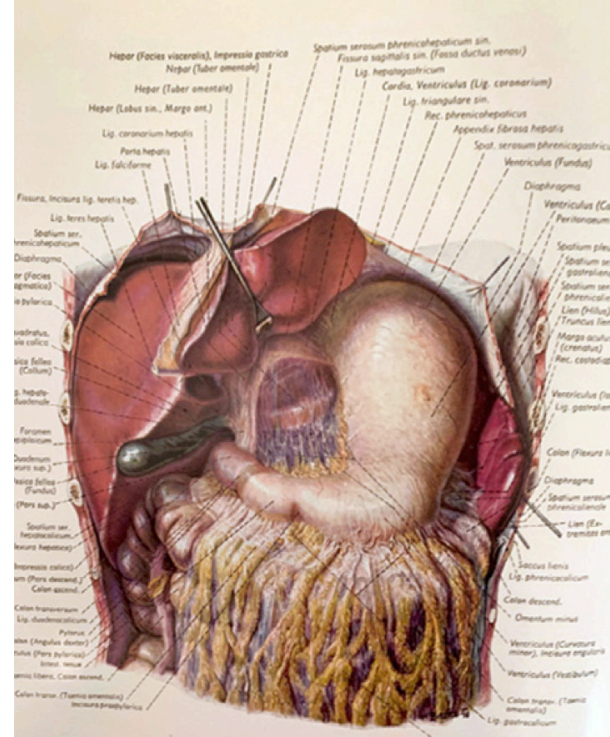

2.a.

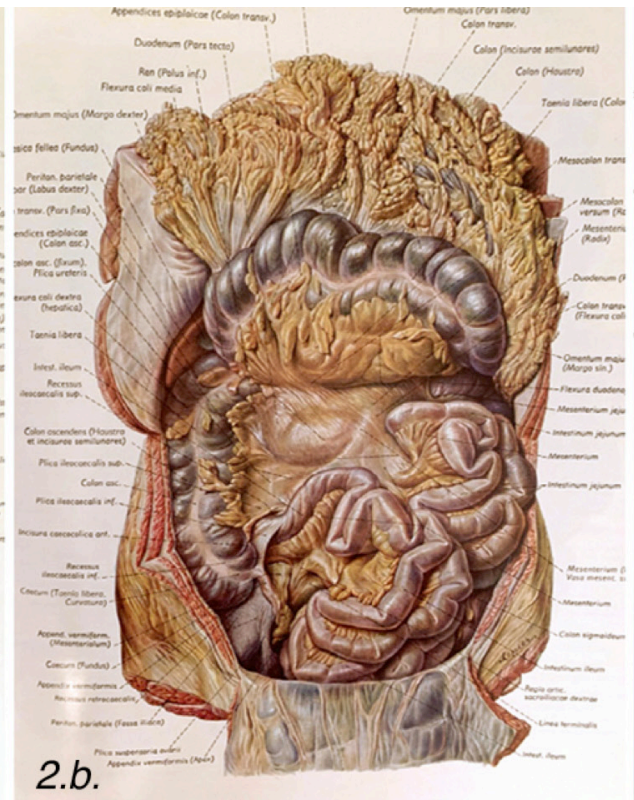

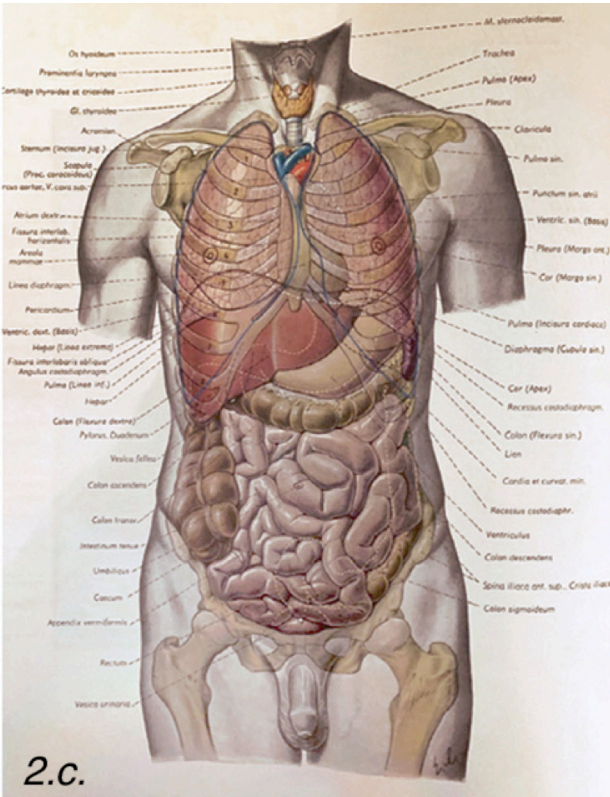

Figure 2.a., 2.b., \& 2.c. From Pernkopf's atlas, volume 2, 1980, permission provided by the Josephinum - Ethics, Collections and History of Medicine, MedUni Vienna. Image credit: 2.a. by Batke (1940; fig. 237) MUW-AD-003250-5-ABB-223; 2.b. by Lepier (no date; fig. 261) $M U W-A D-003250-5-A B B-226$; 2.c. by Lepier (no date; fig. 225), MUW-ZE-003250-0005-0156r.

Ethical issues around the creation of the Pernkopf atlas remained dormant for forty years after the Holocaust, until Dr. Gerald Weissman published his paper in 1985 on Pernkopf's Nazi affiliation and Prof. David Williams published his seminal paper in 1988 on Pernkopf and his artists in the Journal of Biocommunication (reprinted in this issue). The depth of this Nazi legacy was addressed by Dr. William Seidelman and Dr. Howard Israel (Appendix 1: Dr. Seidelman, personal letter to Dr. Israel 1995; Israel \& Seidelman 1996), who brought further attention to this issue by initiating a historic meeting with Yad Vashem officials and representatives from the University of Vienna. The University of Vienna agreed to conduct a detailed investigation on the creation of atlas, the results of which were made public in their 1998 Senatorial Project report (Angetter 2000).

I first became aware of the history of the Pernkopf atlas in 2005, when my University of Toronto colleague and former surgical illustration professor, Margot Mackay gave me a copy of the 1988 Spring volume of the Journal of Biocommunication with David Williams' well-researched paper on Pernkopf and his artists. I am the daughter of Holocaust Survivors. I never dreamt that my personal and professional lives would become intertwined in this way. Over the years I have felt responsible for contributing to the scholarship and preservation of knowledge and artifacts of historical record in this regard.
From the medical art perspective, my focus is on scholarly dissemination to improve informed use of the Pernkopf atlas by:

1. advocating for the creation of an updated information letter to be inserted in as many volumes as possible so that the controversial history of the atlas can be known before use;

2. conducting a research study within the medical art community, to examine knowledge and ethical perceptions on current use in academia and practice; and

3. supporting the creation of a museum archive and permanent exhibition of the original anatomical illustrations to explicate the historical legacy.

In these three ways, opportunities for continued ethical discourse, personal reflection and Holocaust education can be ensured, and can provide necessary acknowledgment to memorialize and honor the nameless victims of the portrayed in this atlas. 


\section{Information Letter and Communication}

The Vienna Protocol provides us with reasoning and guidance for use of the Pernkopf atlas (Polak 2021; 2017). The Untermann Protocol within The Vienna Protocol requires that the history be made known before use and "in this way" it says, "the dead are accorded at least some of the dignity to which they are entitled" (Polak 2021; 2017). One important way that this can be accomplished is with an information letter inserted inside the front cover of each volume of the atlas, to provide potential users with knowledge of the historical facts and ethical issues involved in the creation of the atlas, and then with this information, enable individuals to personally decide on whether to use the atlas or not. This is not a new idea (Appendix 1: Dr. Seidelman, personal letter to Dr. Israel 1995; Seidelman 2017).

In fact, an information letter was created by the University of Vienna, in 1997, signed by Bernd Matouschek, liaison officer, "written on behalf of the Rector of the University of Vienna in the name of Prof. Dr. Alfred Ebenhauer" (Appendix 2). The cover letter states, "I may ask you kindly to add, if possible, the enclosed note of information to your copies of the "Pernkopf-atlases"... all volumes and all editions..." (1997).

The accompanying letter of "Information for the Users of the Pernkopf-atlas" was provided in English and German and indicates:

At present, the possibility cannot be excluded that individual preparations, which were used for drawings... originate from (political) victims of the National Socialist regime. These were delivered by the Wiener Landesgericht (District Court of Vienna). There is also a slight possibility that corpses were delivered from concentrations camps to the Anatomical Institute of the University of Vienna.

It is therefore the ethical responsibility of the individual user to decide whether and in what way he uses this work until the investigation results are published (1997).

The Senatorial investigation report on the University of Vienna Anatomical Institute, published in 1998, concluded that the cadaver register book was missing and was probably destroyed in the air raid of Feb. 7,
1945. They indicate that this was the most important resource where each body assigned to the department of anatomy would have been recorded. Despite the lost document, the Senatorial investigation was able to confirm that:

1377 bodies of executed citizens, including eight of Jewish origin, were assigned to the anatomy department. ... Of the eight victims of Jewish origin, identified as such on the basis of the prison chaplain's report, seven bodies were delivered to the department of anatomy....

With respect to the signatures...it is undisputed that Lepier repeatedly included a swastika in his signature...

The accusation that some of the illustrations in the anatomical atlas might have been based on executed persons, in particular those of Jewish origin, can neither be confirmed nor negated. Of all the 791 illustrations in Pernkopf's anatomical atlas... roughly half...predate 1937 . However, 41 paintings were in fact signed with dates referring to the National Socialist period between 1938 and 1945 and it must be assumed that the models probably came from the group of 1377 executed victims. The remaining 350 illustrations could not be dated and it is possible that some of them were likewise reproduced from Nazi victims (Angetter 2000).

Although the Senatorial Report on the University of Vienna, Anatomical Institute, confirmed the procurement of bodies through the execution of Nazi victims at the District Court, what was forgotten was the necessary update and distribution of the 1997 letter of "Information for the Users of the Pernkopf-atlas." This must not remain undone.

2021 Update: Twenty-four years later, dated July 1, 2021, a new "Note to the Users of Pernkopf's Atlas of Topographical and Applied Human Anatomy" has been created by the Rector, Marcus Müller and the Director of the Josephinum, Prof. Christiane Druml, on behalf of the Medical University of Vienna. We are honoured to publish this important document for this first time in this $J B C$ Special Issue for dissemination, printing and insertion in the atlas. 
In addition, the 2021 "Note to the Users" of the atlas could be disseminated worldwide by targeted emails and made accessible as a downloadable PDF on the Josephinum's and the Medical University of Vienna's Websites, with a request for insertion in all volumes of the atlas. It is essential that this updated information "Note to the Users" be disseminated internationally to institutions (e.g., medical and health professional schools, libraries, hospitals and medical art programs) and to individuals who own personal copies, through professional associations, scholarly presentations and publications.

It is also necessary that appropriate protocols be adopted, i.e., the Untermann Protocol and the Vienna Protocol (Polak 2017) when the atlas is being considered for use in academia, whether in the context of an ethics discussion, Holocaust education, or a history of medical art class, etc. The history of the atlas should be communicated to students before recommending use, and if available, students should receive a copy of the information "Note." Students should be provided with the opportunity to review the history, personally decide and consent to use, or choose a recommended option or alternative to use of the atlas.

\section{Research Study}

The second important aspect that requires illumination within the medical art community necessitates an examination of students', faculties' and practitioners' use of the Pernkopf atlas, whether or not individuals know of the atlas' tainted history, and what their beliefs are around the ethical issues. Recent survey research has been conducted on nerve surgeons by Yee and colleagues, emanating from Dr. Susan Mackinnon's use of the atlas as a surgical resource (2019a, 2019b), followed by another study by Yee and colleagues on maxillofacial surgeons, initiated by Dr. Howard Israel (2020). A similar study needs to be conducted within the medical art community to examine the ethical dilemmas of use and confront the history of the Pernkopf atlas' Nazi legacy, openly and transparently. It is essential that the study results be disseminated throughout the medical art community to promote awareness, discourse and ethical guidelines for future informed use of the Pernkopf atlas in academia and in practice.

\section{Archive and Permanent Exhibition}

The third aspect that I strongly advocate, is for the creation of a museum archive and permanent exhibition of the original Pernkopf anatomical illustrations. Some of the original watercolors are still in existence and until very recently were held by the publishing company, Elsevier, in Munich, Germany (Czech et al. 2021). (Elsevier inherited them in 2003, through a series of corporate mergers and acquisitions, emanating from the 1998 sale of Urban and Schwarzenberg Inc., the original publishers of the Pernkopf atlas.)

The Pernkopf anatomical illustrations are historical artifacts, and therefore it is appropriate for them to move from private ownership into the public domain. Donation and repatriation of the Pernkopf illustrations, from Elsevier to the Medical University of Vienna was initially proposed by Dr. William Seidelman in 1995 at the meeting at Yad Vashem (Appendix 1: Letter from Dr. Seidelman to Dr. Israel 1995).

2021 Update: In Dec. 2019, Elsevier signed an historic agreement, to donate the Pernkopf atlas original anatomical illustrations to the Josephinum. In the summer of 2020, 417 of the original 925 illustrations, from Elsevier's archives (along with 388 printing proofs of the lost originals) were repatriated to the Medical University of Vienna and in January 2021 an announcement was published with details about the donation (Czech et al. 2021).

The Josephinum is the Medical History Museum at the Medical University of Vienna. It holds a rare collection of Italian wax anatomical models, antique medical objects, surgical tools and books. It is a fitting place to archive and exhibit the original Pernkopf anatomical illustrations, to document and disseminate their history, to educate current and future generations and to memorialize the unknown victims. Furthermore, the Pernkopf legacy and a few of the original watercolors could be shared with Holocaust museums internationally, especially Yad Vashem in Jerusalem, Israel, the Holocaust Museum in Washington, D.C. and the Neuberger Holocaust Education Centre, in Toronto, Canada, as well as on the Internet, for dissemination worldwide.

Recently, the Medical University of Vienna made a commitment to transparency and truthful examination of what occurred there during the Holocaust. An informative exhibition, under the direction of Professor Christiane Druml, curated by Professor Herwig Czech and Dr. Niko Wahl, called "The Vienna Faculty of Medicine 1938 to 1945 " was on display at the Josephinum from March 13 to October 6, 2018 (Figure $3)$. (I went to Vienna to view this exhibit.) 


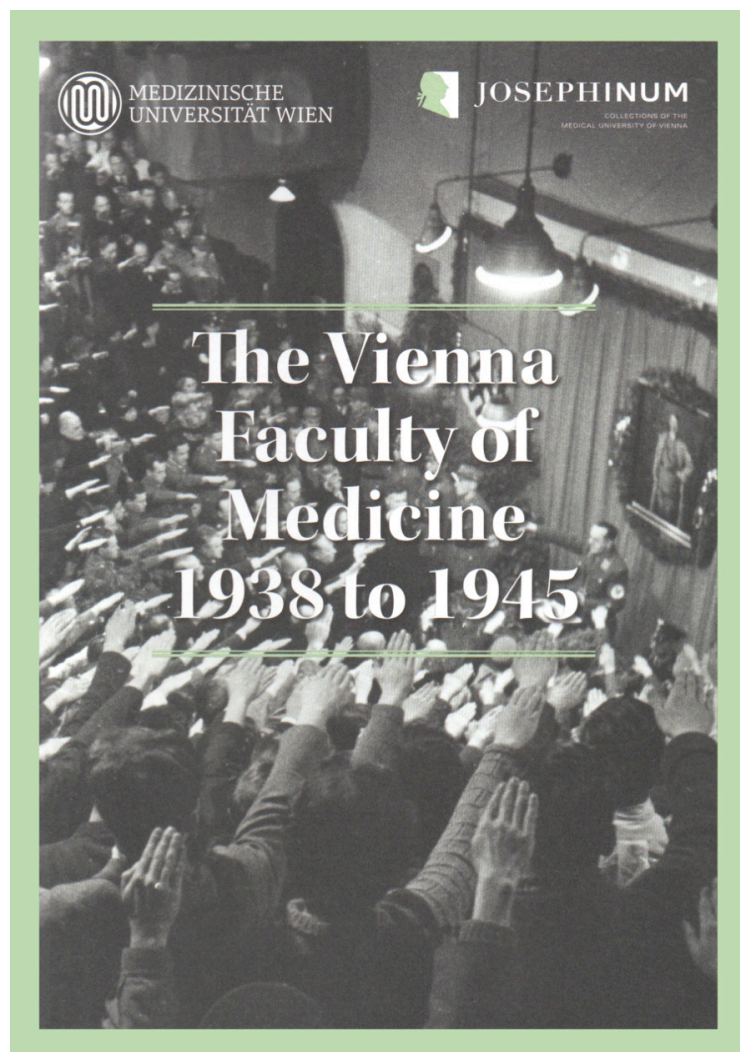

Figure 3. The exhibition took place at the Josephinum, Medical University of Vienna, from March 13 - October 6, 2018. This photo has been licensed and is used with permission of the Österreichische Nationalbibliothek (Austrian National Library, Vienna, Austria), and the Josephinum.
Eighty years after the March 1938 expulsion of all Jewish faculty and students from the Vienna Faculty of Medicine, the university opened its doors to reveal its history and to display numerous remaining artifacts from this dark time. Original documents from medical experiments, like the Dachau salt-water experiments, were on display, as well as a complete set of the first publication of all four German volumes of the Pernkopf atlas, under a glass box.

The catalogue prologue, written by Prof. Dr. Markus Müller, current Rector of the Medical University of Vienna and Professor Christiane Druml, highlights the significance of this endeavor and reads:

We are shaped by our history; yet to the same extent we shape our history through the ways in which we deal with it, through how we speak about the past, which events we remember in what way, and which we do not; how our collective memory shapes what the individual remembers (Müller \& Druml in Czech et. al, 2018).

It is anticipated that a permanent exhibition will be installed at the Josephinum after completion of the current building renovations. However, any permanent exhibition that includes the volumes of the Pernkopf atlas would be incomplete without the original watercolors.

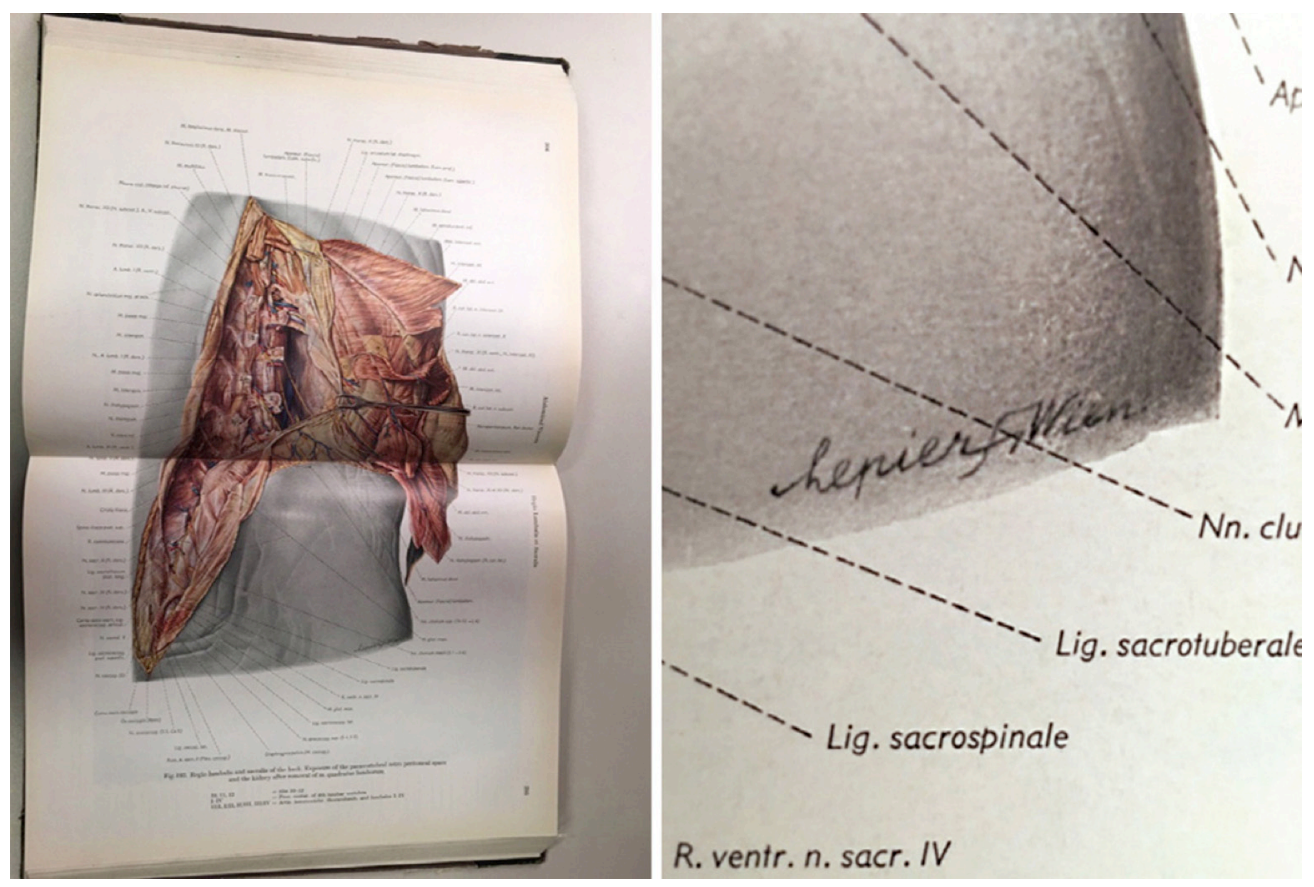

Figure 4. Lepier's signature with swastika Wien (Austria) from Pernkopf's atlas (1963). Permission provided by the Josephinum - Ethics, Collections and History of Medicine, MedUni Vienna. Image credit: MUW-AD-003250-5-ABB-183. 

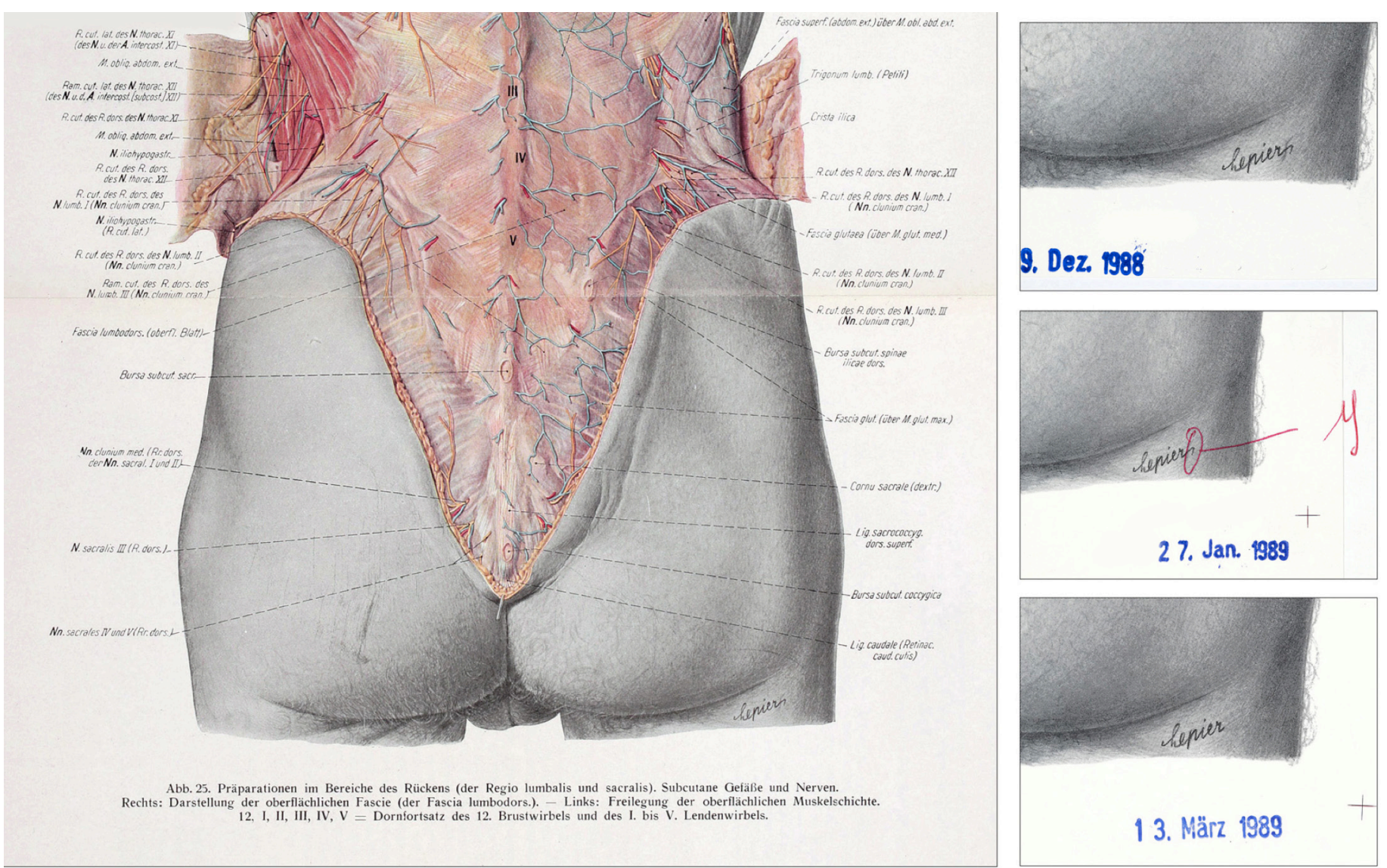

Figure 5. Lepier's signature with publisher's marks for removal of the swastika. Permission provided by the Josephinum-Ethics, Collections and History of Medicine, MedUni Vienna. Image credit: MUW-ILL06-179ll-GESAMTBILD.

These artifacts provide visual evidence and testimony; they carry the historical narrative of the facts (Figure 4). And there are important narratives within the larger narrative that can be easily missed, because facts have been changed, like the removal of the swastikas from most of Lepier's signatures after publication of the first edition of the atlas.

As demonstrated in Dr. Hildebrandt's photo, taken on her visit to Elsevier in Munich, in March 2019 and published herein (Hildebrandt, 2021), the lines of the swastikas in Lepier's signature on some of the anatomical illustrations were removed with sharp object (like an Exacto knife) by picking portions of the vertical swastika line out the surface of the watercolor paper; this left a series of small dots, not visible on reprinting. On other illustrations, as David Williams' $(2004,1988)$ indicated, the vertical line of the swastika was removed in Lepier's signature by painting it out.

To me, the removal of the swastikas from the original watercolors is analogous to changing historical facts deleting details is like erasing evidence (Figure 5). A permanent exhibition with explanations of the historical narratives embedded within the Pernkopf artifacts would document the visual evidence and provide testimony for continued ethical discourse, Holocaust education and informed use of the atlas.

Donation of the Pernkopf anatomical illustrations and creation of a permanent exhibition at the Josephinum also is a way for Elsevier (on behalf of the original publisher Urban \& Schwarzenberg Inc.) to honor and memorialize the unknown identities of the victims portrayed in the atlas. It provides an opportunity to publicly acknowledge and responsibly share these historical artifacts with the world.

\section{Conclusion}

Informed use of the Pernkopf atlas is an imperative. As an ethical standard, ascertained by The Vienna Protocol (Polak 2017), it demands to currently be addressed (Hildebrandt et al. 2021). Moving towards informed use through the dissemination and communication of updated historical information to users of the atlas, a 
research study on knowledge and ethical use within the medical art community, and the installation of a permanent exhibition of the original anatomical illustrations, are important next steps. The Nazi legacy of the Pernkopf atlas continues to unfold and remains relevant. Repatriation of the anatomical illustrations to the Josephinum at the Medical University of Vienna - to be shared, physically and virtually - with Holocaust museums internationally and on the Internet with individuals and institutions worldwide, will ensure preservation of visual testimony, documentation of historical facts, and illuminate ethical concerns. Informed use is essential to future Holocaust educational initiatives (Roelcke et al. 2021; Hildebrandt 2020; Lax 2020; Seidelman et al. 2019; Horton 2019) and gives us pause, to remember and pay tribute to the unknown victims portrayed in the atlas.

Addendum: I am delighted to report that since the Toronto Symposium, in November 2019, that 2 of the 3 items advocated for in this presentation/paper have been realized through the advocacy of the Medical University of Vienna, and are noted in "2021 Updates" within this paper. I am grateful to Professors Herwig Czech, Christiane Druml, Wolfgang Weninger and Rector Markus Müller of the Medical University of Vienna, for their advocacy and contributions to this $2021 J B C$ Special Issue, and for elucidating the Medical University of Vienna perspective, and creating the important 2021 "Note" to inform future users about the history of the atlas.

Acknowledgements: Special thanks to Dr. Sabine Hildebrandt for sharing with me the 1997 cover letter and letter of "Information for the Users of the Pernkopfatlas." Thank you to the Neuberger Holocaust Education Centre for their gracious support and inclusion of our Symposium in Holocaust Education Week 2019 and to Biomedical Communications at the University of Toronto for their generous sponsorship of the Symposium.

\section{Dedication}

The Toronto Symposium and this Journal of Biocommunication Special Issue are dedicated to the memory of all Nazi victims and in honor of the Survivors and their families.

\section{References}

Agur, A. 2021. Anatomical details and accuracy of the Pernkopf atlas and examples of clinical impact. In Lax, L., Schnitz, G. (Eds.), Legacies of medicine in the Holocaust and the Pernkopf atlas. Journal of Biocommunication, Special Issue.

Anderson, J.E. 1978. Grant's Atlas of Anatomy, 7th ed. Baltimore: Williams \& Wilkins.

Angetter, D.C. 2000. Anatomical science at the University of Vienna 1938-45. The Lancet. 355:1445-57.

Czech, H., Brenner, E., 2019. Nazi victims on the dissection table-The anatomical institute in Innsbruck. Annals of Anatomy. 226:84-95.

Czech, H., Druml, C., Müller, M, Voegler, M., Beilmann, A., Fowler, N. 2021. The Medical University of Vienna and the legacy of Pernkopf's anatomical atlas: Elsevier's donation of the original drawings to the Josephinum. Annals of Anatomy. Accessed at: https://doi.org/10.1016/j.aanat.2021.151693.

Czech, H., Wahl, N., Zingler, M., Druml, C. 2018. The Vienna Faculty of Medicine 1938-1945 (exhibition catalogue). Josephinum, Medical University of Vienna.

Hildebrandt, S. 2021. Anatomy in Nazi Germany: The use of victims' bodies in academia and present-day legacies. In Lax, L., Schnitz, G. (Eds.), Legacies of medicine in the Holocaust and the Pernkopf atlas. Journal of Biocommunication, Special Issue.

Hildebrandt, S., Polak, J.A., Grodin, M.A., Seidelman, W.E. 2021. The history of the Vienna Protocol. In Hildebrandt, S., Offer, M., Grodin, M.A. (Eds.), Recognizing the past in the present: New studies on medicine before, during, and after the Holocaust. New York: Berghahn Books, pgs. 354-372.

Hildebrandt, S. 2020. The Vienna Protocol: Medicine's confrontation with continuing legacies of its Nazi past. Annals of Anatomy. 229:151459. Published online January 20, 2020. Accessed at: https://doi.org/10.1016/j.aanat.2020.151459

Hildebrandt, S. 2016. The Anatomy of Murder: Ethical Transgressions and Anatomical Science during the Third Reich. New York: Berghahn Books. 
Hildebrandt, S., Seidelman, W.E. 2018. To use or not to use: The legitimacy of using unethically obtained scientific human tissue from the National Socialist era. In: Czech, H., Druml, C., Weindling, P. (Eds.), Medical ethics in the 70 Years after the Nuremberg Code, 1947 to the present. Wien Klin Wochenschr, 130:S228-S231.

Horton, R. 2019. Offline: Medicine and the Holocaust it's time to teach. The Lancet. 394 (10193):105.

Israel, H.A., Seidelman, W.E. 1996. Nazi origins of an anatomy text: the Pernkopf Atlas. JAMA. 276(20):1633.

Lax, L. 2020. The Toronto Pernkopf Symposium Presentation videos from Neuberger Holocaust Education Week Symposium (Nov. 10, 2019). Published at: https://www.leilalax.ca/research/pernkopf-symposium.

Mackinnon, S., Yee, A. 2021. Before and after I knew: Disclosure, respect, gratitude, and solemnity. In Lax, L., Schnitz, G. (Eds.), Legacies of medicine in the Holocaust and the Pernkopf atlas. Journal of Biocommunication, Special Issue.

Matouscheck, B. 1997. Cover letter and letter of information for users of the Pernkopf-atlas. University of Vienna (Appendix 2).

Müller, M., Czech, H., Druml, C., 2019. Commentary: The Medical University of Vienna and the historic legacy of Pernkopf's atlas. Surgery. 165(5):871-872.

Pernkopf, Eduard. 1980. Atlas of Topographical and Applied Human Anatomy. Volume 1: Head and Neck; Volume 2: Thorax, Abdomen and Extremities, Baltimore and Munich: Urban \& Schwarzenberg.

Pernkopf, Eduard. 1963/4. Atlas of Topographical and Applied Human Anatomy. Volume 1: Head and Neck; Volume 2: Thorax, Abdomen and Extremities, Philadelphia and London: W.B. Saunders.

Polak, J.A. 2017. The Vienna Protocol: for when Jewish or Possibly-Jewish Human Remains are Discovered. In: Seidelman, W.E., Elbaum, L., Hildebrandt, S. (Eds.), How to deal with Holocaust era human remains:

Recommendations arising from a special symposium. Elie Wiesel Center for Jewish Studies, Boston

University, Boston, MA. Accessed at: http://www.bu.edu/jewishstudies/files/2018/08/HOWTO-DEAL-WITH-HOLOCAUST-ERAREMAINS.FINAL .pdf
Polak, J.A. 2021. The Vienna Protocol: For When Jewish or Possibly-Jewish Human Remains are Discovered. In Lax, L., Schnitz, G. (Eds.), Legacies of medicine in the Holocaust and the Pernkopf Atlas. Journal of Biocommunication, Special Issue.

Roelcke, V., Hildebrandt, S., Reis, S. 2021. Announcing the Lancet Commission on medicine and the Holocaust: Historical evidence, implications for today, teaching for tomorrow. The Lancet. 397(10277):862-864. Accessed at: https://doi.org/10.1016/S0140-6736(21)00157-4

Seidelman, W.E. 1995. Personal Letter to Dr. Howard Israel (Appendix 1).

Seidelman, W.E., 2018. The tainted eponym:

Transgression and memory in medical science. In: Czech, H., Druml, C., Weindling, P. (Eds.), Medical Ethics in the 70 Years After the Nuremberg Code, 1947 to the Present, Wien Klin Wochenschr. 130:S186-S190.

Seidelman, W.E., Hildebrandt, S., Mackinnon, S., Polak, J., Agur, A., Berger, P., Lax, L. 2019. The Vienna Protocol: Medicine's confrontation with continuing legacies of its Nazi past. Holocaust Education Week Symposium, Neuberger Holocaust Education Centre. Nov. 10, 2019. Accessed at: https://www.holocaustcentre.com/hew-2019/the-viennaprotocol

Weissmann, G. 1985. Springtime for Pernkopf. Hosp. Pract. (Off. Ed). 20(10):142-168.

Williams, D.J. 1988. The history of Eduard Pernkopf's Topographische Anatomie des Menschen. Journal of Biocommunication. 15(2):2-12.

Williams, D.J. 2004. Is a picture worth a thousand lives? The Twenty-Third Annual Charles Henry Hackley Distinguished Lecture in the Humanities. Muskegon, MI. May 20, 2004. Manuscript.

Yee, A., Coombs, D., Hildebrandt, S., Seidelman, W.E., Coert, J.H., Mackinnon, S.E. 2019a. Nerve surgeons' assessment of the role of Eduard Pernkopf's atlas of topographical and applied human anatomy in surgical

practice. Neurosurgery. 84(2):491-498. Accessed at: https://doi.org/10.1093/neuros/nyy159

Yee, A., Li, J., Lilly, J., Hildebrandt, S., Seidelman, W.E., Brown, D., Kopar, P., Coert, J.H., Mackinnon, S.E., Israel, H.A. 2021. Oral and maxillofacial surgeons' 
assessment of the role of Pernkopf's atlas in surgical practice. Annals of Anatomy - Anatomischer Anzeiger. 234, 151614. Accessed at:

https://doi.org/10.1016/j.aanat.2020.151614

Yee, A., Zubovic, E., Yu, J., Ray, S., Hildebrandt, S., Seidelman, W.E., Polak, J.A., Grodin, M., Coert, J.H., Brown, D., Kodner, I.J., Mackinnon, S.E. 2019b. Ethical considerations in the use of Pernkopf's atlas of anatomy: A surgical case study. Surgery. 165(5):860-867.

Accessed at: https://doi.org/10.1016/j.surg2018.07.025

\section{About the Author}

Leila Lax, an assistant professor in the Master of Science program in Biomedical Communications, Institute of Medical Science, Temerty Faculty of Medicine, University of Toronto, recently retired from teaching after 37 years. Leila taught courses in medical legal visualization and conducted large-scale, curricular design research in medical, interprofessional and health sciences education. She held the 2-time distinction of AMI Commissioner on the Accreditation Review Committee for the Medical Illustrator. Leila's masters and doctoral degrees are in Higher Education with specializations in health professions education and collaborative knowledge building. As a Senior Research Scientist, Institute for Knowledge Innovation and Technology, she continues to coordinate the Palliative Care eLearning Program. Leila's work has been recognized by numerous awards, since her early days as a medical illustrator, for her teaching, research publications, and co-design curricular initiatives. In 2021, Leila was honored with an Ontario Government Volunteer Recognition Award.

Leila Lax, B.A., B.Sc.A.A.M., M.Ed., Ph.D.

Assistant Professor (retired), Biomedical Communications, Institute of Medical Science, Temerty Faculty of Medicine, University of Toronto

Contact:1.1ax@utoronto.ca

\section{Licensing}

The author has chosen to license this content under a Creative Commons Attribution, NonCommercial, NoDerivatives 4.0 International License.

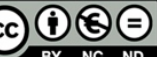

Authorization for publication of images from Pernkopf's atlas has been granted for use in this article only. The atlas images must remain within the context of this article for open-access, scholarship and educational use. The atlas images in this article may not be removed from this article, nor reproduced, nor distributed, outside of the context of this article, for scholarly, education or commercial purposes, without the expressed permission of the Josephinum.

\section{Image Credit}

The Journal of Biocommunication wishes to thank the Josephinum and the Medical University of Vienna for approving the publication of Pernkopf atlas images that used within this Special Issue. These images may appear on the cover, in the Table of Contents and as figures within articles, and are acknowledged with the following image credit:

\section{Josephinum - Ethik, Sammlungen und Geschichte der Medizin, MedUni Wien}

\section{Josephinum - Ethics, Collections and History of Medicine, MedUni Vienna}

\section{Conflict of Interest Statement}

The Journal of Biocommunication Management Board and Editors believe that transparency in academic research is essential. Our $J B C$ authors are now required to disclose any possible conflict of interest when submitting a manuscript. In accordance with the Journal of Biocommunication's editorial policy, no potential conflict of interest has been reported or declared by this author. 
Appendix 1: Dr. William Seidelman, personal letter

to Dr. Howard Israel, 1995.

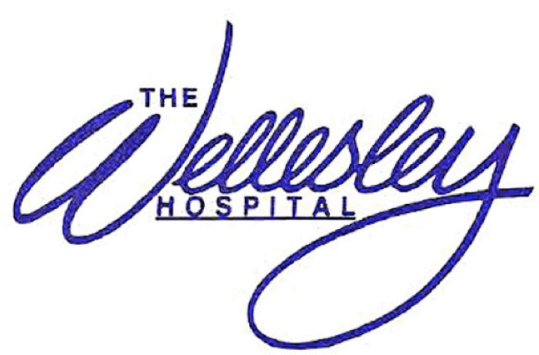

A University Hospital with a Commitment to Community

January 10, 1995

Dr. Howard Israel

Associate Professor, Columbia University

47 Park Circle

Great Neck, New York

11024 U.S.A.

fax: $\quad 212-305-9017$

Dear Dr. Israel,

Having just recently returned from Israel, I am writing to report on a meeting I had with officials of Yad Vashem on the morning of Thursday, December 29, 1994, at Yad Vashem in Jerusalem. The subject of the meeting was the Eduard Pernkopf human anatomical collection and the illustrations of this collection as published by Urban and Schwarzenberg. The Yad Vashem officials in attendance were:

Brig. Gen. (Res.) Avner Shalev, Chairman of the Directorate

Ambassador (Ret.) Reuven Dafni, Vice Chairman

Mr. Yaacov Lozowick, Chief Archivist

Information on this issue had been previously sent to Yad Vashem via Mr. Lozowick. General Shalev and Ambassador Dafni were aware of these materials. In addition I left with them a photocopy of the catalogue entitled "The Urban and Schwarzenberg Collection of Medical Illustrations Since 1896" and the article by David Williams (Journal of Biocommunication, Vol. 15, Spring 1988) on Pernkopf. It should be noted that Mr. Williams makes reference in his article to 1977 correspondence with Yad Vashem concerning subjects used as specimens in the Pernkopf collection.

The discussions included consideration of my experience of the past 5 years in dealing with the matter of the human pathoanatomical specimens from Nazi victims in the collections of some German universities and research institutes.

The Yad Vashem officials agreed to assume a responsibility and to undertake the initiatives required to bring this matter to a proper resolution. The discussion focussed on whether there should be public or private approaches. It was agreed that the initial approach should be 160 Wellesley Street East, Toronto, Ontario M4Y 1J3

A University of Toronto Teaching Hospital 
private with a public approach to be reserved if the private efforts prove unsuccessful. The approaches would be to:

1. The Institute of Anatomy of the University of Innsbruck

2. The Institute of Anatomy of the University of Vienna

3. Urban and Schwarzenberg Inc.

4. The Chancellor of Austria

Gen. Shalev and Amb. Dafni indicated that the Chancellor of Austria had been a recent visitor to Israel and Yad Vashem and that he should be informed of this matter.

You and I were requested to assist in the formulation of the letters which would be sent by Yad Vashem.

With respect to strategy I believe it is important to consider the recent German experience where every effort was made to deflect accountability and responsibility in properly documenting the truth with respect to the origins of the human subjects used for some pathoanatomical collections. While suspect specimens were identified in a number of German collections in only one instance, notably the Karl-Eberhard University of Tübingen, was there a proper investigation with outside experts and a report in the public domain. It should be noted that the former director of the Institute of Anatomy at the University of Tübingen, Prof. Arnold, attempted to dismiss questions concerning the Tübingen collection. Investigation revealed that the Tübingen Institute had, in fact, received over 400 cadavers of Nazi victims; principally Russian and Polish slave labourers executed by the Gestapo in Stuttgart. The Max Planck Society initially denied that it had in its collections specimens from Nazi victims. The Max Planck Society subsequently acknowledged that collections at the Max Planck Institute of Brain Research in Frankfurt and the Max Planck Institute of Psychiatry in Munich included specimens derived from Nazi victims; principally victims of the T-4 and "wild" euthanasia programs. There was no proper published official documentation on the Max Planck collections. More recently I have had correspondence with the universities of Heidelberg and Munich concerning investigations of their collections which may contain specimens from Nazi victims. Both institutions rejected the suggestion.

The Tübingen model, which I feel should be put forward to the parties in Austria, consisted of a committee of investigation comprised of outside experts chaired by an eminent lawyer, Professor Albin Eser, who is an expert on medical ethics. The committee was struck by the senate of the university. Membership included an historian familiar with the history of the anatomy institute, a Swiss anatomist, a medical student and the leader of the Jewish community of the state of Baden-Württemberg. The committee produced an official report which is now in the public domain and may be obtained from the office of the president of the University of Tübingen.

The procrastination, obfuscation and obstruction of the other German institutions occurred despite widespread publicity both inside and outside Germany. Indeed, a supposed investigation by the Standing Conference of the Ministers of Culture of the German Länder was initiated after a formal complaint to the German embassy in Tel-Aviv by the Government of 
Israel following international publicity. With the exception of Tübingen, all of the investigations were superficial, incomplete or inadequately documented.

Another excuse put forward by German government officials was that responsibility for the anatomical collections in the universities rested with the governments of the states in which the universities resided and not with the federal government. Thus the German federal officials could claim that they had no jurisdiction in the matter.

I believe the problem with the German investigations is that there was no proper external system for monitoring or for holding the responsible authorities accountable. Despite the efforts of the Government of Israel, nobody outside of Germany appears to have been responsible for follow-up. Indeed, it is uncertain that the German authorities even submitted their report to the Government of Israel or if there was a knowledgeable person designated by the Government of Israel to receive such information. The German authorities could dismiss the complaint of the Government of Israel by saying that their inquiries did not reveal that any specimens had been derived from Jewish subjects.

It should also be noted that the Tübingen inquiry occurred only as a result of the pressure of a group of medical students, one of whom was a member of the university senate. The motion to establish the Tübingen inquiry passed the university senate by one vote namely that of the medical student.

The differences with the approach presently being proposed are:

1. There is a designated credible body (e.g. Yad Vashem) to which there will be accountability and which will be responsible for ensuring that the appropriate authorities undertake a proper investigation.

2. The proposed investigative model is based on an established German example namely that of the University of Tübingen.

3. The expected outcome is being defined at the outset.

4. A public approach can always be used if all else fails

With respect to outcome, I would suggest the following:

1. There must be proper documentation copies of which should be deposited in the archives of Yad Vashem.

2. There must be an official published report in the public domain.

3. Specimens shown to have been derived from Jews, which are larger than glass slides, must receive a proper burial in a Jewish cemetery. This is based on an official rabbinical decision (December, 1992) made with respect to suspect specimens in the collection of the Institute of Anatomy of the Ludwig-Maximillian University of Munich.

4. There should be a public acknowledgement and commemoration to the victims by the institutions and organizations concerned. 
As for the Urban and Schwarzenberg collection of anatomical illustrations and publications thereof, I agree that the collection should not be altered and that publication of the Pernkopf illustrations should continue even if it is established that some of the illustrations are from subjects whose death occurred because of Nazi crimes. If it is established that some of the subjects were, or possibly could have been, Nazi victims the publisher should include at the very beginning of any publication or public display of the work an acknowledgement of the origins of those specimens and a commemoration to the victims. I also agree that the illustrations containing symbols of a swastika or "SS" should not be altered but should, in fact, be acknowledged.

With respect to the involvement of the Anti-Defamation League, I informed the Yad Vashem officials of the interest of the ADL and included a copy of your correspondence with ADL officials. I personally believe that the best approach would be a joint one between Yad Vashem and the ADL rather than two independent initiatives. However, that is something for the two organizations to decide amongst themselves.

I hope this result is satisfactory to you and the suggestions contained herein acceptable.

Yours sincerely,

William E. Seidelman, M.D.

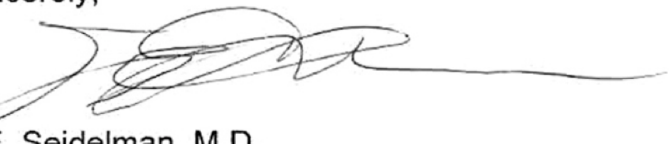

Professor

Department of Family and Community Medicine

University of Toronto

Medical Director

HIV Ambulatory Program

The Wellesley Hospital

cc:

Brig. Gen. (Res.) Avner Shalev

Chairman of the Directorate, Yad Vashem

Ambassador (Ret.) Reuven Dafni

Vice-Chairman, Yad Vashem

Yaacov Lozowick

Chief Archivist, Yad Vashem

Marc Edelman

Director, Marketing and Communications Division

Anti-Defamation League 
Appendix 2: Cover letter and letter of "Information

for the Users of the Pernkopf-atlas."

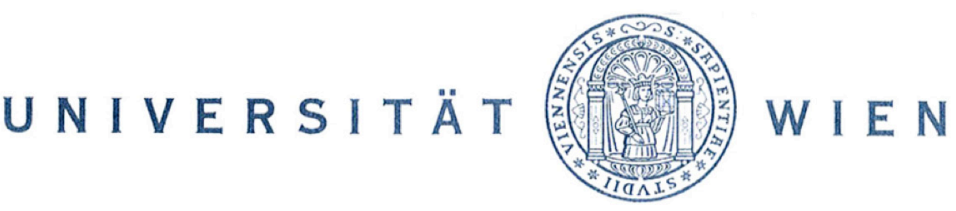

Vienna, November 1997

Subject: Enclosure of the "Information for the Users of the Pernkopf-atlases"

In the name of the Rector of the University of Vienna, Prof. Dr. Alfred Ebenbauer, I may ask you kindly to add, if possible, the enclosed note of information to your copies of the "Pernkopf-atlases" (Eduard Pernkopf: "Topographische Anatomie des Menschen. Lehrbuch und Atlas der regionär-stratigraphischen Präparation." [Topographic Human Anatomy...] all volumes and editions.) and to forward it to relevant libraries linked to yours.

As you can see from the note of information, there are justified doubts regarding the ethic non-objection of individual pictures. Until the full discovery of the historical facts concerning their sources, we consider it necessary to inform the public, in particular the users of the atlases in the German-speaking as well as in the English-speaking area about these circumstances.

We hope that our request does not cause great inconvenience.

If you have any further questions on this matter, please contact me at the given address.

Thank you for your support.

Kind regards,

Bewnd Alatouscer

Bernd Matouschek

Enclosure

We have a new phonenumber $(+43$ 1) $4277-18101,-18102$ and a new faxnumber (+43 1) 42779181

Öffentlichkeitsarbeit . Mag. Bernd Matouschek

Dr. Karl Lueger-Ring 1. A-1010 Wien. Telefon (+43-1) 401033437 


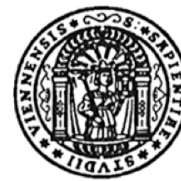

\section{INFORMATION FÜR BENUTZER DES PERNKOPF-ATLANTEN}

Anfang 1997 wurde von der Universität Wien eine offizielle wissenschaftliche Projektgruppe mit der Untersuchung ungeklärter Fragen zum Ursprung einiger anatomischer Abbildungen im „Pernkopf-Atlas“ betraut: Es soll hierbei geklärt werden, ob eventuell einzelne Abbildungen auf der Basis von Leichen oder Leichenteilen von Opfern des nationalsozialistischen Gewaltregimes in Österreich entstanden sind.

Eduard Pernkopfs „Topographische Anatomie des Menschen. (...)“ ist 1937-1960 in vier Bänden (mit mehreren Teilbänden) im Verlag Urban und Schwarzenberg erschienen, die Bände 1 bis 3 bereits vor 1945. In den folgenden Jahrzehnten wurde der Pernkopf-Atlas mehrmals in verschiedenen Varianten (andere Vorwörter, retuschierte Bildsignaturen [ohne Hakenkreuze oder stilisierte SS-Runen]) neu aufgelegt.

Prof. Eduard Pernkopf (1888-1955) war ein hochrangiger österreichischer Nationalsozialist. Von 1938-1945 war er Dekan der Medizinischen Fakultät Wien und von 1943-1945 Rektor an der Universität Wien.

Es kann derzeit nicht ausgeschlossen werden, daß einzelne Präparate, die für Zeichnungen in diesen Atlanten herangezogen wurden, von (politischen) Opfern des nationalsozialistischen Gewaltregimes stammen. Es ist darüber hinaus derzeit noch unklar, ob Leichen damals außer vom Wiener Landesgericht eventuell auch von Konzentrationslagern an das Anatomische Institut der Universität Wien geliefert wurden.

Es muß daher bis zur Veröffentlichung der Untersuchungsergebnisse in die ethische Verantwortung des einzelnen Benutzers gelegt werden, ob und in welcher Art und Weise er dieses Werk nutzt.

Die Untersuchungskommission wird voraussichtlich Mitte bis Ende 1998 einen detaillierten Bericht über die Ergebnisse veröffentlichen.

m. p. Bernd Matouschek

$\begin{array}{ll}\text { Außeninstitut der Universität Wien } & \text { Wien, November } 1997\end{array}$

Information for English speaking user, please turn over! 


\section{U N I V E R S I T Ä T}

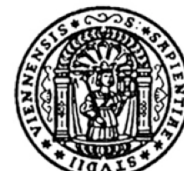

W I E N

\section{INFORMATION FOR THE USERS OF THE PERNKOPF-ATLAS}

In the beginning of 1997 an official scientific project team was commissioned by the University of Vienna to investigate still opaque questions concerning the origin of several anatomic illustrations in the so-called Pernkopf-atlas: the aim is to clarify if some of the anatomic reproductions were produced on the basis of corpses or parts of corpses of victims of the National Socialist despotism.

Eduard Pernkopf's „Topographische Anatomie des Menschen (...)" ('Topographic Human Anatomy') was published between 1937 and 1960 in four volumes (with several parts) by the publishing house Urban und Schwarzenberg, the volumes 1 to 3 before 1945. In the following decades the Pernkopf-atlas was republished several times in different variants (different forewords, retouched captions [without swastika or stylized SS-runes]). The Pernkopf-atlas was also published in several editions in English, a Spanish translation followed in 1953.

Professor Eduard Pernkopf (1888-1955) was a high-ranking Austrian National Socialist. Between 1938 and 1945 he was dean at the Medical Faculty of Vienna and between 1943 and 1945 rector of the University of Vienna.

At present, the possibility cannot be excluded that individual preparations, which were used for drawings in the anatomical atlas published by Eduard Pernkopf, originate from (political) victims of the National Socialist regime. These were delivered by the Wiener Landesgericht (District Court of Vienna). There is also a slight possibility that corpses were delivered from concentration camps to the Anatomical Institute of the University of Vienna.

It is therefore the ethical responsibility of the individual user to decide whether and in what way he uses this work until the investigation results are published.

The investigation committee will probably publish a detailed account of the results in the second half of 1998 .

m.p. Bernd Matouschek

Liason Office; University of Vienna

Vienna, November 1997 